\title{
Hexokinase of Escherichia coli. Assay of Enzyme Activity and Adaptation to Growth in Various Media
}

\author{
By ANNA M. PAKOSKEY, EILEEN C. LESHER AND \\ DWIGHT B. MCNAIR SCOTT
}

Department of Physiology, School of Medicine, and Interdisciplinary Cancer Research Unit, School of Veterinary Medicine, University of Pennsylvania, Philadelphia, Pennsylvania 19104, U.S.A.

(Received 29 July 1964)

\section{SUMMARY}

Hexokinase was determined in extracts of Escherichia coli by measurement of the reduction of nicotinamide-adenine dinucleotide phosphate by glucose-6-phosphate dehydrogenase, and the glucose-6-phosphate formed by the action of hexokinase. This method gave reproducible results. Extracts of $\boldsymbol{E}$. coli contained low hexokinase activity when the organism had been grown in the absence of glucose and this enzyme activity was increased after adaptation of the organism to growth on glucose. The $\boldsymbol{E}$. coli needed 2-2.5 divisions to reach the degree of hexokinase activity of glucose-grown bacteria when transferred to salts + glucose from media not containing glucose.

\section{INTRODUCTION}

Previous studies (Scott \& Chu, 1959) showed that glucose-6-phosphate (G-6-P) dehydrogenase activity was higher in extracts of Escherichia coli when the bacteria had been grown in the presence of glucose than when grown in media containing other sources of carbon. Phosphogluconate (PG) dehydrogenase activity was relatively constant in the extracts from bacteria grown in different media. In further studies of the uptake and utilization of glucose by $\boldsymbol{E}$. coli, the activity of hexokinase was determined to see whether it behaved like G-6-P or PG dehydrogenase (see below). It was found that certain changes in the media involving carbon sources or other additions produced changes in the degree of activity of the hexokinase in extracts which were not, however, as great as the changes in G-6-P dehydrogenase.

$$
\begin{gathered}
\text { Glucose }+ \text { ATP } \underset{\mathrm{Mg}^{2+}}{\stackrel{\text { hexokinase }}{\rightarrow} \text { glucose-6-phosphate } \frac{\text { G-6-P dehydrogenase }}{\mathrm{NADP}^{+}, \mathrm{Mg}^{2+}} \rightarrow} \\
\text { phosphogluconate } \frac{\text { PG dehydrogenase }}{\mathrm{NADP}^{+}, \mathrm{Mg}^{2+}} \text { ribulose-5-phosphate }
\end{gathered}
$$

\section{METHODS}

The method for cultivation of 'weekly' and 'overnight' cultures was described previously (Scott \& Chu, 1959). The cultures of Escherichia coli strain B were grown at $37^{\circ}$ in an aerated medium of Bacto-beef extract and Bacto-peptone (Difco 
Laboratories, Detroit, Michigan, U.S.A.) or salts media (Cohen \& Arbogast, 1950), with glucose $2 \mathrm{mg} . / \mathrm{ml}$. medium. Casein hydrolysate (an acid hydrolysate of casein; General Biochemicals, Inc., Chagrin Falls, Ohio, U.S.A.) $4 \mathrm{mg} . / \mathrm{ml}$. medium, or Difco yeast extract (the water-soluble portion of autolysed fresh yeast) $2 \mathrm{mg} . / \mathrm{ml}$. medium, was added to the salts media instead of glucose as indicated.

The 'weekly' culture, which was a salts + glucose culture, was used to inoculate two 'overnight' cultures of either one form of salts medium or nutrient broth. One culture was harvested to be extracted. The other was centrifuged and the bacteria were resuspended in salts medium to inoculate the final cultures, which were allowed to grow $1,1.5$ or 2 divisions as noted in Table 1 . The harvested organisms were washed in saline, recentrifuged, the bacterial pellet weighed, ground with alumina $(2.5 \times$ wet weight) in the cold and extracted with $0.05 \mathrm{M}$-tris buffer adjusted to $\mathrm{pH} 7 \cdot 4$ with $2 \mathrm{~N}-\mathrm{HCl}$. The extracts were centrifuged $1 \mathrm{hr}$ at $10,000 \mathrm{~g}$ at $4^{\circ}$ in an International Refrigerated Centrifuge PR-2. The amounts of protein in the extracts were determined by light extinction after precipitation with $10 \%(\mathrm{w} / \mathrm{v})$ perchloric acid.

The methods of measurement of G-6-P and PG dehydrogenases were as reported previously (Scott \& Cohen, 1953). The direct method for the hexokinase reaction

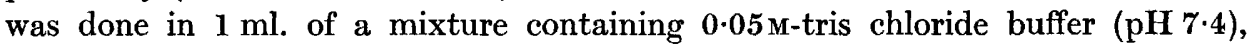
$1 \mu$ mole glucose, $10 \mu$ moles $\mathrm{MgSO}_{4}, 0.02 \mathrm{~N}$-nicotinamide and extract containing 0.05-1 mg. protein. NADP ${ }^{+}$was added and the endogenous reaction recorded. With the addition of $1 \mu$ mole ATP, the G-6-P formed was oxidized by the G-6-P dehydrogenase, permitting the rate of NADPH formation to be measured at $340 \mathrm{~m} \mu$ at $37^{\circ}$ in a Beckman DU spectrophotometer. Two other methods were also used for comparison; these were measurement of glucose removed and measurement of G-6-P formed. The mixture described above that was used for the direct measurement was incubated in a $37^{\circ}$ water bath and $1 \mathrm{ml}$. samples removed at selected times into cold $\mathrm{HCl}(0.04 \mathrm{~mm})$. After centrifugation at $4^{\circ}$, the supernatant fluid was neutralized with $\mathrm{NaOH}(0.04 \mathrm{M})$. Glucose and G-6-P concentrations were measured in the samples. The glucose was determined by the 'Glucostat', a preparation of glucose oxidase (Worthington Biochemical Corp., Freehold, New Jersey, U.S.A.). The assay for G-6-P was done in $1 \mathrm{ml}$. of a mixture of $0.05 \mathrm{M}$-tris chloride buffer (pH 7.4), $10 \mu$ moles $\mathrm{MgSO}_{4}, 0 \cdot 4 \mu$ mole NADP+ and the sample. Purified G-6-P dehydrogenase was added and the total formation of NADPH was measured in a Beckman DU spectrophotometer at $340 \mathrm{~m} \mu$ at $37^{\circ}$. The G-6-P dehydrogenase was obtained either from Sigma Chemical Co. (St Louis, Missouri, U.S.A.) or was purified in our laboratory from extracts of Escherichia coli by methods previously reported (Scott \& Cohen, 1953).

\section{RESULTS}

Figure 1 shows the rate of reduction of NADP+ by G-6-P formed when ATP was added to mixtures of glucose and an extract of Escherichia coli grown in salts + glucose medium. The rate of reaction with G-6-P indicated that G-6-P dehydrogenase was present in large excess in the extract and was not limiting in the measurement of the rate of the hexokinase reaction. In the hexokinase assay during the first few minutes the G-6-P formed was limiting; then a constant rate was attained which was taken as the measure of the hexokinase activity. There was no NADPH oxidase activity in these extracts when magnesium ions were present unless oxidized 
glutathione was added. There was slight or no activity with ATP or glucose omitted. The presence of nicotinamide inhibited NADP+ase. It was not necessary to make corrections for NADPH produced by PG dehydrogenase since the NADPH was in high enough concentration to inhibit PG dehydrogenase activity. The presence of some activator in the extracts was indicated by the lack of proportionality of activity to protein content at low dilutions of extracts, as is illustrated in Fig. 2.

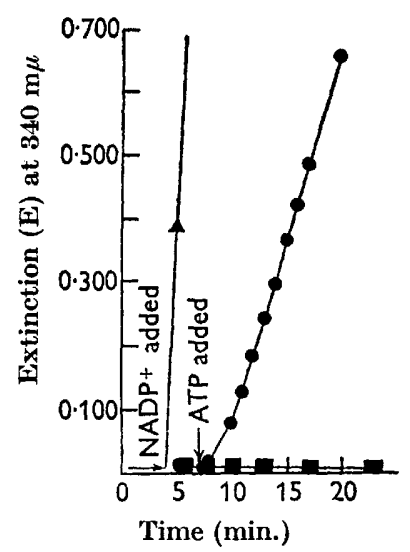

Fig. 1

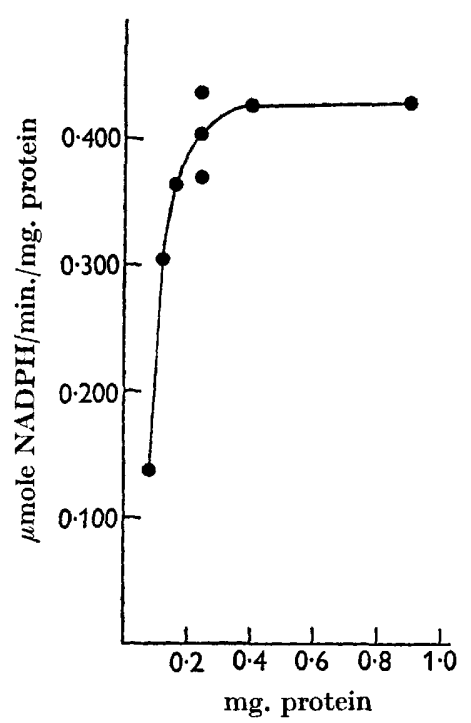

Fig. 2

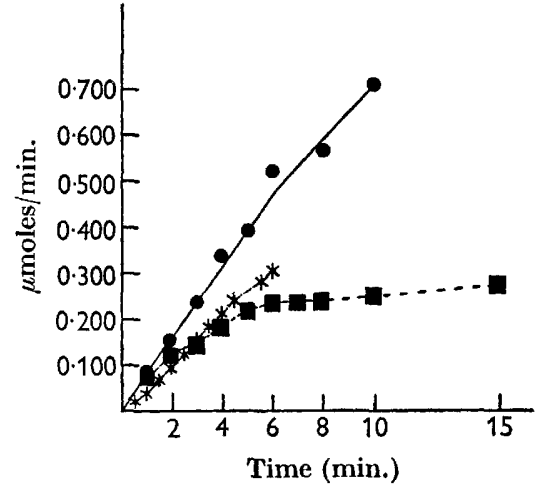

Fig. 3

Fig. 1. Hexokinase of extracts of Escherichia coli grown in salts + glucose medium. Each $1.5 \mathrm{ml}$. cuvette contained $10 \mu$ moles $\mathrm{MgSO}_{4}, 0.01 \mathrm{ml}$. extract (equiv. $81 \mu \mathrm{g}$. protein). $\Delta$, G-6-P dehydrogenase reaction: $1 \mu$ mole G-6-P, 0.05 M-tris chloride buffer (pH 8.7). , Hexokinase reaction: $0.05 \mathrm{M}$-tris chloride buffer ( $\mathrm{pH} 7 \cdot 4), 1 \mu$ mole glucose, $1 \mu$ mole nicotinamide; $0.03 \mathrm{ml}$. NADP $+(10 \mathrm{mg} . / \mathrm{ml}$. $)$ was added to each cuvette. After $3 \mathrm{~min}$. $1 \mu$ mole ATP was added. Total volume was $1 \mathrm{ml}$. $\square$, Hexokinase reaction with either ATP or glucose omitted. Extinction, E, at $340 \mathrm{~m} \mu$ was read on a Beckman DU spectrophotometer at $37^{\circ}$.

Fig. 2. Effect of sample size on hexokinase activity. The sample used was an extract from a salts + glucose culture of Escherichia coli that contained equiv. $8.1 \mathrm{mg}$. protein $/ \mathrm{ml}$. The other contents of the cuvette were as in Fig. 1.

Fig. 3. Comparison of three methods to determine hexokinase of Escherichia coli extracts. The extract used was from bacteria grown on salts + glucose medium and contained equiv. $9 \cdot 82 \mathrm{mg}$. protein $/ \mathrm{ml}$. The methods are explained in the Method section. The direct method $\left(^{*}\right)$ was a measurement of $\mu$ mole $\mathrm{NADPH} / \mathrm{ml}$. reaction mixture. The glucose uptake method (C) was a measurement of $\mu$ mole glucose removed $/ \mathrm{ml}$. reaction mixture and the G-6-P measurement ( $\boldsymbol{D}$ ) was a measurement of $\mu$ mole G-6-P found $/ \mathrm{ml}$. reaction mixture.

The comparison of the three methods used for determination of hexokinase is shown in Fig. 3. The initial rates of glucose disappearance and appearance of G-6-P were the same for the first $2 \mathrm{~min}$. After $2 \mathrm{~min}$. the G-6-P was metabolized by other pathways, so that it became unavailable for measurement. The glucose was taken up at a decreasing rate because of the inhibition of hexokinase by G-6-P formed and not removed (Crane \& Sols, 1954). 
Table 1. Effect of transfer of Escherichia coli to different media on enzyme activities*

\begin{tabular}{|c|c|c|c|c|c|c|c|}
\hline & \multirow[b]{2}{*}{$\begin{array}{c}\text { Number } \\
\text { of } \\
\text { divisions }\end{array}$} & \multicolumn{2}{|c|}{ Hexokinase } & \multicolumn{2}{|c|}{$\begin{array}{c}\text { G-6-P } \\
\text { dehydrogenase }\end{array}$} & \multicolumn{2}{|c|}{$\begin{array}{c}\text { PG } \\
\text { dehydrogenase }\end{array}$} \\
\hline Medium & & $\begin{array}{c}\text { Units/ } \\
\text { mg. } \\
\text { protein }\end{array}$ & $\begin{array}{c}\text { Units/ } \\
10^{9} \\
\text { bacteria }\end{array}$ & $\begin{array}{c}\text { Units/ } \\
\text { mg. } \\
\text { protein }\end{array}$ & $\begin{array}{c}\text { Units/ } \\
10^{9} \\
\text { bacteria }\end{array}$ & $\begin{array}{c}\text { Units/ } \\
\text { mg. } \\
\text { protein }\end{array}$ & $\begin{array}{c}\text { Units/ } \\
\mathbf{1 0}^{9} \\
\text { bacteria }\end{array}$ \\
\hline
\end{tabular}

Inoculum nutrient
broth (overnight)

A. $\frac{1}{2}$ vol. nutrient broth $+\frac{1}{2}$ vol. salts + glucose divisions protein bacteria

protein bacteria

B. Salts + glucose

II. Inoculum

-

$100 \quad 100$$$
100 \quad 100
$$$$
100
$$

100

$$
\begin{aligned}
& 400 \\
& 164
\end{aligned}
$$

$110 \quad 137$

92

232

110
116

76

$\begin{array}{lr}1 & 92 \\ 1 & 100 \\ 1 & 52 \\ 1 \cdot 5 & 206 \\ 1 \cdot 5 & 150\end{array}$

$86 \quad 112$

$112 \quad 112$

$$
\begin{aligned}
& 112 \\
& 274 \\
& 227
\end{aligned}
$$$$
132
$$

\section{3}

86

212
59

218

227

96

200

271

132

158

97

105

$1 \cdot 5$

100

100

100

313

100

186

salts + glucose
A. $\frac{1}{2}$ vol. nutrient broth $+\frac{1}{2}$ vol. salts + glucose

B. Nutrient broth

1

74

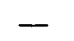

56

78

100

III. Inoculum $\frac{7}{2}$ vol. nutrient broth + $\frac{1}{2}$ vol. salts + glucose

Nutrient broth

IV. Inoculum salts + casein hydrolysate (overnight)

Salts + glucose

$\begin{array}{ll}1 & 34 \\ 2 & 4 \\ \mathbf{3} & 5 \\ 3 & 5\end{array}$

$\begin{array}{rrrrrrr}1 & 34 & 6 & 32 & 6 & 109 & 19 \\ 2 & 44 & - & 57 & - & 82 & -19 \\ 2 & 52 & 10 & 76 & 14 & 106 & 19 \\ 3 & 54 & - & 60 & - & - & -19 \\ 3 & 56 & 12 & 54 & 10 & 96 & 100 \\ 1 & 100 & 100 & 100 & 100 & 100 & 100\end{array}$

Inoculum salts +
casein hydrolysate +
yeast extract
(overnight)
Salts + glucose

VI. Inoculum salts + yeast extract (overnight)

Salts + glucose

$\begin{array}{lrrrrrr}1 & 162 & 150 & 182 & 170 & 105 & 100 \\ 1 & 170 & 200 & 126 & 158 & 91 & 113 \\ 1 \cdot 5 & 218 & 225 & 300 & 290 & 110 & 107 \\ 1 \cdot 5 & 168 & 230 & 167 & 239 & 114 & 160 \\ 1 \cdot 5 & 100 & 100 & 100 & 100 & 100 & 100 \\ & & & & & & \\ 1 & 107 & 325 & 186 & 590 & 118 & 338 \\ 1 & 67 & 125 & 114 & 216 & 108 & 219 \\ 1 \cdot 5 & 110 & 400 & 161 & 620 & 106 & 375 \\ 1 \cdot 5 & 106 & 350 & 163 & 426 & 118 & 333\end{array}$

* The enzyme activities of the inoculum were set at 100 . 
Table 1 lists the results from experiments testing the effects of growth in different media on values of hexokinase activity. The activity of the original inoculum is taken as $100 \%$. In the first series (I), the overnight inoculum was grown in nutrient broth. When the bacteria were transferred to media of equal parts of nutrient broth and salts + glucose, in only one division striking increases (3-fold) were found in hexokinase activity. The Escherichia coli grown on nutrient broth were smaller in size than those organisms grown on defined media with glucose. This difference in size was reflected in differences in enzyme activity $/ 10^{9}$ bacteria as compared to activity/ mg. protein. The G-6-P dehydrogenase showed some fluctuation but the PG dehydrogenase (/mg. protein) remained in the same range for all the series with a mean

Table 2. Average division times of growing cultures of Escherichia coli

\begin{tabular}{|c|c|c|c|}
\hline Inoculum & Medium & Division & $\begin{array}{c}\text { Time } \\
\text { (min.) }\end{array}$ \\
\hline Salts + glucose & Salts + glucose & $\begin{array}{l}1 \\
\mathbf{2} \\
\mathbf{3}\end{array}$ & $\begin{array}{l}73 \\
60 \\
60\end{array}$ \\
\hline Nutrient broth & Salts + glucose & $\begin{array}{l}1 \\
1 \cdot 5\end{array}$ & $\begin{array}{r}175 \\
48\end{array}$ \\
\hline Salts + casein hydrolysate & Salts + glucose & $\begin{array}{l}1 \\
1.5 \\
2\end{array}$ & $\begin{array}{c}108,78^{*} \\
48 \\
67^{*}\end{array}$ \\
\hline Salts + yeast extract & Salts + glucose & $\begin{array}{l}1 \\
1.5\end{array}$ & $\begin{array}{r}105 \\
40\end{array}$ \\
\hline $\begin{array}{l}\text { Salts }+ \text { casein hydrolysate }+ \\
\text { yeast extract }\end{array}$ & Salts + glucose & $\begin{array}{l}1 \\
1.5\end{array}$ & $\begin{array}{r}142 \\
52\end{array}$ \\
\hline Salts + glucose & Nutrient broth & $\begin{array}{l}1 \\
2 \\
3\end{array}$ & $\begin{array}{l}62 \\
58 \\
46\end{array}$ \\
\hline $\begin{array}{l}\frac{1}{2} \text { vol. salts }+ \text { glucose }+ \\
\frac{1}{2} \text { vol. nutrient broth }\end{array}$ & Nutrient broth & 1 & 30 \\
\hline Nutrient broth & Nutrient broth & 1 & 65 \\
\hline Nutrient broth & $\left.\begin{array}{l}\frac{1}{2} \text { vol. nutrient broth }+ \\
\frac{1}{2} \text { vol. salts }+ \text { glucose }\end{array}\right\}$ & 1 & 70 \\
\hline Salts + glucose & $\left.\begin{array}{l}\frac{1}{2} \text { vol. nutrient broth }+ \\
\frac{1}{2} \text { vol. salts }+ \text { glucose }\end{array}\right\}$ & $\begin{array}{l}2 \\
1\end{array}$ & $\begin{array}{l}88 \\
62\end{array}$ \\
\hline Salts + casein hydrolysate & Salts + casein hydrolysate & $\begin{array}{l}1 \\
2\end{array}$ & $\begin{array}{l}95 \\
70\end{array}$ \\
\hline Salts + yeast extract & Salts + yeast extract & $\begin{array}{l}1 \\
2\end{array}$ & $\begin{array}{l}75 \\
60\end{array}$ \\
\hline $\begin{array}{l}\text { Salts }+ \text { yeast extract }+ \\
\text { casein hydrolysate }\end{array}$ & $\left.\begin{array}{c}\text { Salts }+ \text { yeast extract }+ \\
\text { casein hydrolysate }\end{array}\right\}$ & $\mathbf{1}$ & 90 \\
\hline
\end{tabular}

of $97.5 \% \pm 11$ (S.D.). When the overnight inoculum grown in nutrient broth was put into salts + glucose containing no nutrient broth, the first division was delayed. Division occurred at $175 \mathrm{~min}$. instead of $73 \mathrm{~min}$. when the inoculum was grown in salts + glucose. The hexokinase ranged from 50 to $100 \%$ of control but, at $\frac{1}{2}$ division time (48 min.) later, the activity increased sharply. Table 2 shows a comparison of division times in different media.

In series II (Table 1) where the bacteria were grown in salts + glucose for two divisions and then were transferred to media made up of equal parts salts + glucose 
and nutrient broth for 1 division, the hexokinase activity was decreased $25 \%$ and the G-6-P dehydrogenase was decreased 50\%. When bacteria grown in salts + glucose + nutrient broth media for one division (Table 1, series III) were transferred to nutrient broth for 1 division, the activity of both enzymes fell $40 \%$ from their previous values or $80 \%$ from the original salts + glucose values. Series II (Table 1) shows the greater decreases when bacteria grown on salts + glucose ( 2 divisions) were transferred to nutrient broth for 1 division. Both hexokinase and G-6-P dehydrogenase activities were only $30 \%$ of original values/mg. protein. When the Escherichia coli organisms were allowed to grow 2 or 3 divisions in nutrient broth, the activity of both enzymes levelled off at $50 \%$ of original activity of the salts + glucose inoculum. The activity of both enzymes $/ 10^{9}$ bacteria decreased to $15 \%$ of those grown in glucose because the bacteria were so much smaller.

Bacteria grown in salts + casein hydrolysate overnight and transferred to salts +

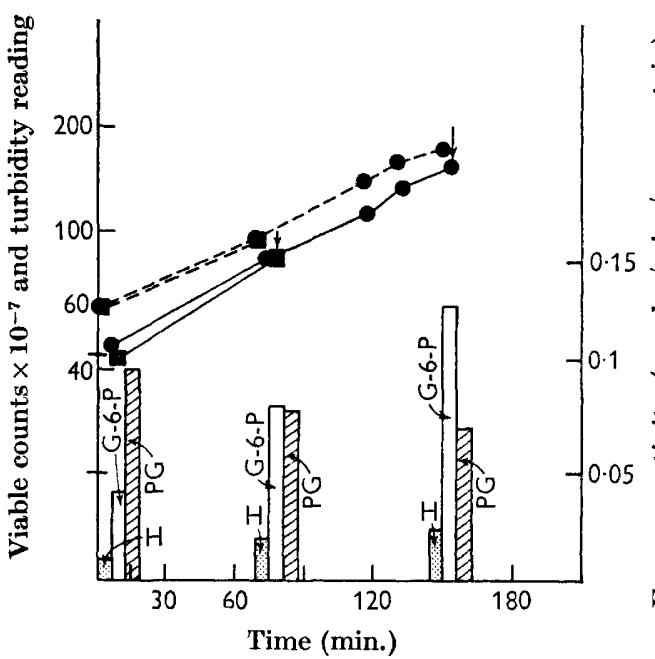

Fig. 4

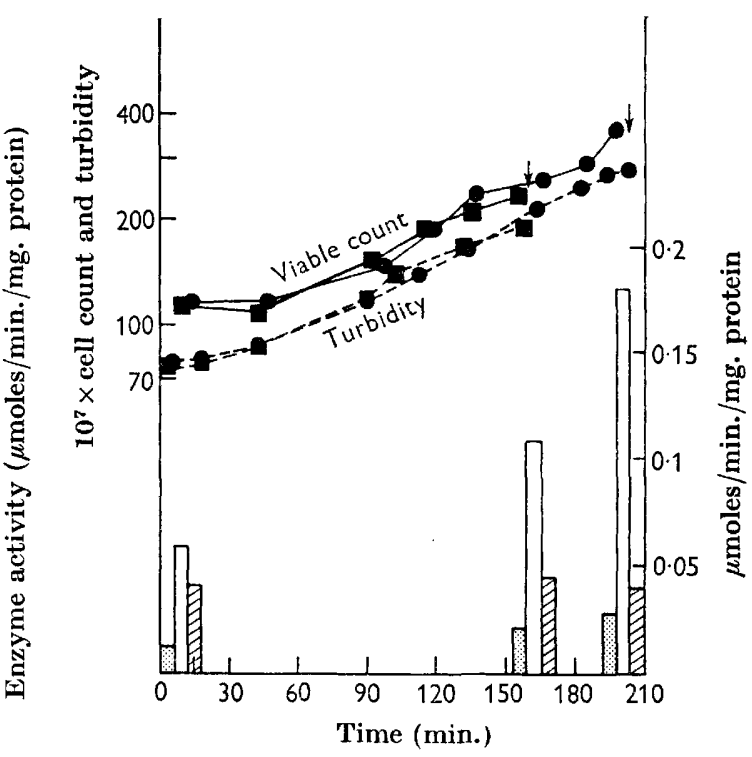

Fig. 5

Fig. 4. Growth and enzyme values of Escherichia coli grown in salts + casein medium and transferred to salts + glucose medium. Two towers each containing $200 \mathrm{ml}$. of salts + casein medium were grown overnight. One was harvested to be extracted; the other was centrifuged, the organisms washed and suspended in salts medium. This suspension was used to inoculate two towers each containing total $200 \mathrm{ml}$. salts medium + glucose $(2 \mathrm{mg}$. $/ \mathrm{ml}$. $)$. Turbidity curves are shown as - - - and viable cell counts as - . Arrow $\downarrow$ indicates time of harvesting. Enzyme activities of the extracts of the washed pellets expressed in $\mu$ mole $\mathrm{NADP}+/ \mathrm{min}$./mg. protein are shown in the histograms, shaded for hexokinase $(\mathrm{H})$, clear for G-6-P dehydrogenase and cross-hatched for PG dehydrogenase. The turbidity was measured with a $420 \mathrm{~m} \mu$ filter in the Klett photometer at the time of harvest is indicated by $\log _{2} T / T_{0}$.

Fig. 5. Growth and enzyme values of Escherichia coli grown in salts + casein + yeastextract medium and transferred to salts + glucose medium. Two towers each containing $200 \mathrm{ml}$. of salts + casein + yeast-extract were grown overnight. One was harvested for extraction and the other was centrifuged, washed and suspended in salts medium. This was used to inoculate two towers each containing total $200 \mathrm{ml}$. salts medium with glucose $(2 \mathrm{mg} . / \mathrm{ml}$.). Symbols are as in Fig. 4. 
glucose showed a two- to threefold increase in activity of hexokinase and G-6-P dehydrogenase as seen in series IV (Table 1). When the overnight cultures also had yeast extract added (Table 1, series V), the same pattern resulted. However, when the overnight inoculum was grown in salts + yeast extract (Table 1, series VI), there was essentially no gain in hexokinase activity $/ \mathrm{mg}$. protein and a $1 \cdot 5-4$-fold gain $/ 10^{9}$ bacteria. The G-6-P dehydrogenase showed a gain of $1 \cdot 5-$ fold $/ \mathrm{mg}$. protein and of $2-6$-fold $/ 10^{9}$ bacteria. Figures 4 and 5 show typical experiments with turbidity and enzyme activities plotted.

\section{DISCUSSION}

The experiments showed that the spectrophotometric method for determining hexokinase was reproducible. Cochrane, Peck \& Harrison (1953) showed with extracts of a Streptomyces a reduction of NADP+ by glucose and ATP and by G-6-P dehydrogenase and PG dehydrogenase, indicating the presence of hexokinase. Changes in hexokinase activity in Escherichia coli could be induced by changes in media. The hexokinase activity was increased after changes from media not containing glucose to media containing glucose. It was reported by Damodaran, Jagannathan \& Singh (1955) for an Aspergillus that most of the enzymes of the glycolytic pathway and the hexosemonophosphate shunt, including hexokinase, decreased as the culture aged while growing on glucose and accumulating citrate. Hamilton \& Dawes $(1959,1960,1961)$ reported that $P$ seudomonas aeruginosa, when grown on medium containing half glucose and half citric acid from an inoculum grown on citric acid, used first the citric acid and then the glucose, so that a 'diauxie' was shown. However, when the inoculum organism was grown on glucose, both citric acid and glucose were metabolized simultaneously. In our experiments when Escherichia coli grown on nutrient broth was used to inoculate a medium containing half salts + glucose medium and half nutrient broth, there was a lag while the hexokinase built up, and then growth began. The $E$. coli needed 2.5 divisions to reach the degree of hexokinase activity of glucose-grown bacteria when transferred to salts + glucose from any medium tested, except casein hydrolysate + yeast extract, which needed only 2 divisions. The mechanism of adaptation must be the same as or similar to that reported by Hamilton \& Dawes. There does not seem to be a substance in the casein hydrolysate, yeast extract or nutrient broth which acts as a repressor of hexokinase because glucose induced hexokinase in their presence. In an attempt to find the activator in the extracts a whole series of amines and other compounds were tested in our system. A report of these results is in preparation.

A preliminary report of a part of this work was presented at the Fifty-Ninth General Meeting of the Society of American Bacteriologists, May, 1959. This study was supported by grants C 4170 and CY 2189 from the National Cancer Institute, National Institutes of Health, United States Public Health Service.

\section{REFERENCES}

Cochrane, V. W., Peck, Jr., H. D. \& Harrison, A. (1953). The metabolism of species of Streptomyces. VII. The hexosemonophosphate shunt and associated reactions. J. Bact. 66, 17.

Cohen, S. S. \& Arbogast, R. (1950). Chemical studies in host-virus interactions. J. exp. Med. 91, 619. 
Crane, R. K. \& Sols, A. (1954). The non-competitive inhibition of brain hexokinase by glucose-6-phosphate and related compounds. J. biol. Chem. 210, 597.

Damodaran, M., Jagannathan, V. \& Singh, K. (1955). Carbohydrate metabolism in citric acid fermentation. III. The variation in glycolytic enzyme content of Aspergillus niger during citric acid fermentation. Enzymol. 17, 199.

Hammton, W. A. \& Dawes, E. A. (1959). A diauxic effect with Pseudomonas aeruginosa. Biochem. J. 71, 25 P.

Hamilton, W. A. \& Dawes, E. A. (1960). The nature of the diauxic effect with glucose and organic acids in Pseudomonas aeruginosa. Biochem. J. 76, 70 P.

Hamilton, W. A. \& Dawes, E. A. (1961). Further observations on the nature of the diauxic effect with Pseudomonas aeruginosa. Biochem. J. 79, 25 P.

Scotr, D. B. M. \& Crro, E. (1959). The oxidative pathway of carbohydrate metabolism in Escherichia coli. 6. Adaptation of glucose-6-phosphate dehydrogenase to growth in complex media. Biochem. J. 72, 426.

ScotT, D. B. M. \& Cohen, S. S. (1953). The oxidative pathway of carbohydrate metabolism. 1. The isolation and properties of glucose-6-phosphate dehydrogenase and 6phosphogluconate dehydrogenase. Biochem. J. 55, 23. 